jury chairman, Emilie V. Wiggins, 2950 Newark St., N.W., Washington, DC 20008. Staff liaison, Mrs. Carol Raney Kelm.

Isadore Gilbert Mudge Citation. A citation to be given at the Annual Conference of the ALA to a person who has made a distinguished contribution to reference librarianship. This contribution may take the form of an imaginative and constructive program in a particular library; the writing of a significant book or articles in the reference field; creative and inspirational teaching of reference service; or other noteworthy activities which stimulate reference librarians to more distinguished performance. Donated and administered by the Reference Services Division. Deadline for nominations, March 15, 1972. Send nominations to jury chairman, Walter Allen, Graduate School of Library Science, University of Illinois, Urbana, IL 61801. Staff liaison, Andrew Hansen.

Esther J. Piercy Award. An annual citation presented in recognition of a contribution to librarianship in the field of the technical services by younger members of the profession. The recipient will be a librarian with not more than ten years of professional experience who has shown outstanding promise for continuing contributions and leadership in any of the fields comprising technical services by such means as: (a) leadership in professional associations at local, state, regional, or national levels; (b) contributions to the development, application, or utilization of new or improved methods, techniques, and routines; (c) a significant contribution to professional literature; (d) conduct of studies or research in the technical services. The award will be given each year in which the jury believes there is a qualified recipient. Donated and administered by the Resources and Technical Services Division. Deadline for nominations, January 1, 1972. Send nominations to jury chairman, Mrs. Roma S. Gregory, Head, Acquisitions Dept., University of Rochester, Rochester, NY 14627. Staff liaison, Mrs. Carol Raney Kelm.

ALA Scholarship Program. ALA Scholarship Program, approved by the ALA Council, January 1969, provides scholarships, in the amount of $\$ 2,500$, to be given annually to worthy students to begin and/or further their library education at the graduate level without regard to race, creed, color, or national origin. The recipients must enter a formal program of graduate study leading to a degree or advanced certificate at an ALA-accredited school. As many scholarships as possible will be awarded, depending upon the total amount of contributed funds. The award may be withheld in any year when there are no worthy recipients. Administered by ALA Awards Committee and the Library Education Division. Applications must be submitted by December 10, 1971. Application and recommendation forms are available from the jury chairman, J. Phillip Immroth, Graduate School of Library and Information Science, University of Pittsburgh, Pittsburgh, PA 15213. Staff liaison, Delores Vaughan.

Library Binding Institute Scholarship. An annual scholarship of $\$ 1,000$ made to a worthy student to further his library education. It is made to a resident of the United States without regard to race, color, creed, or geographical origin. Donated by the Library Binding Institute. Administered by the Library Education Division. Applications must be submitted by January 10, 1972. Information and application forms are available from the jury chairman, Martin Cohen, School of Librarianship, Western Michigan University, Kalamazoo, MI 49001. Staff liaison, Delores Vaughan.

Exhibits Round TABLE. An annual award of $\$ 500$ made to an individual or a group to aid or improve some particular aspect of librarianship or library service on the basis of need in the profession or in the operation of professional library associations. Donated and administered by the Exhibits Round Table. Chairman: To be appointed. Nominations should be forwarded before the ALA conference to the staff liaison, Chris Hoy.

Herbert W. Putnam Honor Fund Award. An award of $\$ 500$ presented at intervals as a grant-in-aid to an American librarian of outstanding ability for travel, writing, or other use that might improve his or her service to the library profession or to society. Administered by the ALA Awards Committee which serves as the jury. Nominations should be sent to Robert F. Delzell, Director of Personnel, University of Illinois Library, Urbana, IL 61801. Staff liaison, Judith F. Krug.

The chairman of the ALA Awards Committee is Robert F. Delzell, Director of Personnel, University of Illinois Library, Urbana, IL 6180I.

\section{ACQUIRE RARE MANUSCRIPT}

A facsimile of the New Testament portion of Codex Vaticanus, one of the most important ancient manuscripts of the Vatican Library, has been presented to the DuKe UNIVErsity library as a gift from Pope Paul VI. The presentation of the copy of this fourth-century manuscript was made by Dr. Howard Wilkinson to university librarian Benjamin E. Powell in a special ceremony in the Rare Book Room, Perkins Library, on September 24, 1971, at which Dr. Kenneth Clark, professor emeritus, and Father Roland Murphy, professor of old Testament of the Duke Divinity School, spoke about the significance of the manuscript. 